\title{
INTERACTIONS OF BACTERIA AND FUNGI ON DECOMPOSING LITTER: DIFFERENTIAL EXTRACELLULAR ENZYME ACTIVITIES
}

\author{
Anna M. Romani, ${ }^{1,3}$ Helmut Fischer, ${ }^{2,4}$ Cecilia Mille-Lindblom, ${ }^{2}$ and Lars J. Tranvik ${ }^{2}$ \\ ${ }^{1}$ Institute of Aquatic Ecology, Department of Environmental Sciences, University of Girona, Campus de Montilivi, \\ 17071- Girona, Spain \\ ${ }^{2}$ Limnology/Department of Ecology and Evolution, Evolutionary Biology Centre, Uppsala University, Norbyv. 20, \\ SE-75236 Uppsala, Sweden
}

\begin{abstract}
Fungi and bacteria are key agents in plant litter decomposition in freshwater ecosystems. However, the specific roles of these two groups and their interactions during the decomposition process are unclear. We compared the growth and patterns of degradative enzymes expressed by communities of bacteria and fungi grown separately and in coexistence on Phragmites leaves. The two groups displayed both synergistic and antagonistic interactions. Bacteria grew better together with fungi than alone. In addition, there was a negative effect of bacteria on fungi, which appeared to be caused by suppression of fungal growth and biomass accrual rather than specifically affecting enzyme activity. Fungi growing alone had a high capacity for the decomposition of plant polymers such as lignin, cellulose, and hemicellulose. In contrast, enzyme activities were in general low when bacteria grew alone, and the activity of key enzymes in the degradation of lignin and cellulose (phenol oxidase and cellobiohydrolase) was undetectable in the bacteria-only treatment. Still, biomass-specific activities of most enzymes were higher in bacteria than in fungi. The low total activity and growth of bacteria in the absence of fungi in spite of apparent high enzymatic efficiency during the degradation of many substrates suggest that fungi provide the bacteria with resources that the bacteria were not able to acquire on their own, most probably intermediate decomposition products released by fungi that could be used by bacteria.
\end{abstract}

Key words: antagonism/synergism; bacteria; extracellular enzyme activity; freshwater-ecosystem litter degradation; fungi; leaf decomposition.

\section{INTRODUCTION}

Microorganisms, mainly bacteria and fungi, are key agents involved in litter breakdown and mineralization (Kuehn et al. 1999). Decomposition of plant litter in lakes and wetlands can be largely performed by fungi, which dominate microbial biomass and production (Kominkova et al. 2000, Kuehn et al. 2000, Findlay et al. 2002). While bacteria contribute to plant litter decomposition in standing waters (Anesio et al. 2003), they are generally considered less important for decomposition of detrital material than fungi, at least during the early stages (Newell 1993, Kominkova et al. 2000), although contrasting results are reported from some systems (e.g., Gaur et al. 1992).

The microbes need to produce extracellular enzymes to convert polymeric compounds - such as cellulose, hemicellulose, and lignin - into smaller molecules that can be assimilated (Chróst 1991). The most relevant enzymes from this aspect involve those that break down the plant fibers (cellulases, hemicellulases, pectinases, phenol oxidases) as well as enzymes important for microbial

\footnotetext{
Manuscript received 17 June 2005; revised 31 January 2006; accepted 28 March 2006. Corresponding Editor: J. P. Schimel.

3 E-mail: anna.romani@udg.es

4 Present address: German Federal Institute of Hydrology, Am Mainzer Tor 1, 56068 Koblenz, Germany.
}

acquisition of nitrogen and phosphorus (peptidases, ureases, and phosphatases) (Sinsabaugh et al. 2002). The enzymes enabling the degradation and utilization of chitin ( $\beta$-glucosaminidases and chitinases) may also cause lysis of fungal cell walls (degradation of fungal cell wall for fungal growth and/or fungal lysis by bacterial action, Wohl and McArthur 2001). Due to the close connection between enzyme activity and degradation of different fractions of organic matter, enzyme assays can be used to estimate degradation rates of particulate and dissolved organic carbon in freshwater systems (Sinsabaugh et al. 1994).

Fungi, in general, produce a wider range of extracellular enzymes than bacteria (Kirk and Farrell 1987). Terrestrial fungi, in particular basidiomycetes, can have high enzymatic capacities, and are therefore able to degrade even highly recalcitrant detritus, such as wood (Kirk and Farrell 1987, Deacon 1997). Even truly aquatic species produce a wide range of enzymes including pectinases, hemicellulases, cellulases, and chitinases (Zemek et al. 1985, Suberkropp 1992, Abdel-Raheem and Shearer 2002). Some species even produce lignin-degrading enzymes (Fisher et al. 1983, Shearer 1992, Bucher et al. 2004).

Production of cellulolytic and xylanolytic (hemicellulolytic) enzymes has been reported to occur also in bacteria (Robb et al. 1979, Tanaka 1993, Sala and Güde 2004). In a few cases, bacteria (particularly actino- 
mycetes) have been shown to contribute to degradation of lignin, either as primary decomposers (Benner et al. 1984), or through mineralization of intermediate products released through fungal activity (Rüttimann et al. 1991). However, it is generally assumed that bacteria mainly decompose polysaccharides and polymeric compounds after the previous decomposition of highmolecular and/or lignified compounds by fungi.

The complete decomposition of plant litter requires the combined actions of a diverse range of microorganisms (Slater and Lovatt 1984). Bacteria and fungi, with their respective extracellular enzyme capabilities, act together in the decomposition and mineralization of plant material in aquatic ecosystems. Due to their similar function as decomposers, and close spatial proximity, interactions most likely have developed between bacteria and fungi. There could be either antagonism, caused by competition for substrates or space, or synergism, if one of the groups can benefit from intermediate decomposition products released by the other. In the terrestrial environment, some antagonistic relationships between bacteria and fungi are well known, such as the release of fungicides or chitinolytic enzymes by bacteria (Lloyd and Lockwood 1966, Weller 1988 ) and the release of antibiotics by fungi (Drews 2000), as well as synergistic effects such as those occurring in the rizosphere. However, few studies describe these interactions in the aquatic habitat, where controlling factors for microbial growth might be different from those in terrestrial habitats. Antagonism has been reported in several recent papers (Wohl and McArthur 2001, Gulis and Suberkropp 2003a, MilleLindblom and Tranvik 2003), while synergism has been reported more sparsely (Bengtsson 1992). The studies of bacterial-fungal interactions in aquatic ecosystems have so far focused mainly on biomass development and overall functions, such as total organic-matter degradation. Our main purpose was to elucidate the specific qualitative differences in the performance of bacteria and fungi in the degradation process, and how this performance responds to coexistence between fungi and bacteria. In this paper we report differences in the patterns of expression of degradative enzymes between communities of bacteria and fungi depending on whether they grow separately or coexist.

\section{Methods \\ Experimental procedure}

A laboratory experiment was performed, incubating sterilized Phragmites leaves with different inocula: natural bacteria, fungi, and bacteria plus fungi. A sterile control and a treatment with nonsterilized leaves were also included. Biomass development and activities of extracellular enzymes involved in decomposition of polysaccharides (cellulose, hemicellulose), lignin, chitin, peptides, and organic phosphorus compounds were followed during 61 days.
Leaves of Phragmites australis (Cav.) Steud. were collected in March 2004 from a tributary of Lake Mälaren in southeastern Sweden (see Plate 1). Leaves were collected from the upper part of the plants on a dry day and preserved in the freezer $\left(-20^{\circ} \mathrm{C}\right)$. At the beginning of the experiment in June 2004, short pieces of leaves were placed in 50-mL polypropylene tubes (45mg dry mass to each tube). All leaves were sterilized (autoclaved) except for those used in the treatment with nonsterilized leaves. Fifteen milliliters of Milli-Q water were added to these tubes, which were autoclaved at $121^{\circ} \mathrm{C}$ for $60 \mathrm{~min}$. To prevent high concentration of leached dissolved organic carbon (DOC) after autoclaving, water was removed after one day using a sterilized silicone tube and a vacuum pump. After that, $12 \mathrm{~mL}$ of artificial lake water (Milli-Q water and $15 \mathrm{mg}$ of anhydrous $\mathrm{CaCl}_{2}$ per liter, $15 \mathrm{mg}$ of (hydrated) $\mathrm{MgSO}_{4}$ $\times 7 \mathrm{H}_{2} \mathrm{O}$ per liter, and $20 \mathrm{mg}$ of $\mathrm{NaHCO}_{3}$ per liter, autoclaved for $30 \mathrm{~min}$ at $121^{\circ} \mathrm{C}$ ) was added to each tube, including those with nonsterilized leaves. The leaves were incubated either with a bacterial inoculum (B treatment), fungal inoculum ( $\mathrm{F}$ treatment), or fungal plus bacterial inoculum $(\mathrm{F}+\mathrm{B}$ treatment). A sterile control $(\mathrm{C})$ and the nonsterilized leaves ( $\mathrm{L}$ treatment) were also included, and 210 tubes were prepared for each treatment. All tubes were agitated at $20^{\circ} \mathrm{C}$ in darkness.

The bacterial inoculum was produced from Phragmites litter (about 10-g wet mass), which was homogenized for 1 min with a kitchen mixer after suspension in $200 \mathrm{~mL}$ of artificial lake water. The resulting suspension was centrifuged at $1000 \mathrm{~g}\left(9807 \mathrm{~m} / \mathrm{s}^{2}\right)$ for $15 \mathrm{~min}$ and the supernatant was collected. The supernatant was filtered through a Whatman $\mathrm{GF} / \mathrm{C}$ filter $(1.4-\mu \mathrm{m}$ pore size) and afterwards through a Whatman $\mathrm{GF} / \mathrm{F}$ filter $(0.7-\mu \mathrm{m}$ pore size) and kept at $4{ }^{\circ} \mathrm{C}$. To assure that the inoculum was free from fungi (at least for all those that can grow on agar), aliquots of $100 \mu \mathrm{L}$ were spread on nutrient agar plates containing 50-mg streptomycin/L and 50-mg ampicillin/L. The plates were checked after 10 days at $20^{\circ} \mathrm{C}$. The inoculum was adapted to $20^{\circ} \mathrm{C}$ for one week prior to experiment start-up, when $30 \mu \mathrm{L}$ of the bacterial suspension with $\sim 10^{10}$ bacterial cells $/ \mathrm{mL}$ were added to each sample of the $\mathrm{B}$ and $\mathrm{F}+\mathrm{B}$ treatments.

The fungal inoculum consisted of five different strains previously isolated and cultured on Hagem agar plates (Mille-Lindblom and Tranvik 2003). The strains used were Alternaria alternata (Fries:Fries) von Keissler, Fusarium chlamydosporum Wollenweber \& Reinking, Botrytis cinerea complex Persoon: Fries, Phoma glomerata (Corda) Wollenw. \& Hochapfel, and one unidentified strain (CBS Identification Services, Utrecht, The Netherlands). All strains were isolated from macrophyte litter in 2003, except for A. alternata, which was isolated in 2001. For the $\mathrm{F}$ and $\mathrm{F}+\mathrm{B}$ treatment the five strains were inoculated using a sterile loop. To check the growth of the fungal inocula, samples from all treatments containing fungi $(\mathrm{F}, \mathrm{F}+\mathrm{B}, \mathrm{L})$ of day 29 , as well as samples from pure fungal cultures of the five species 


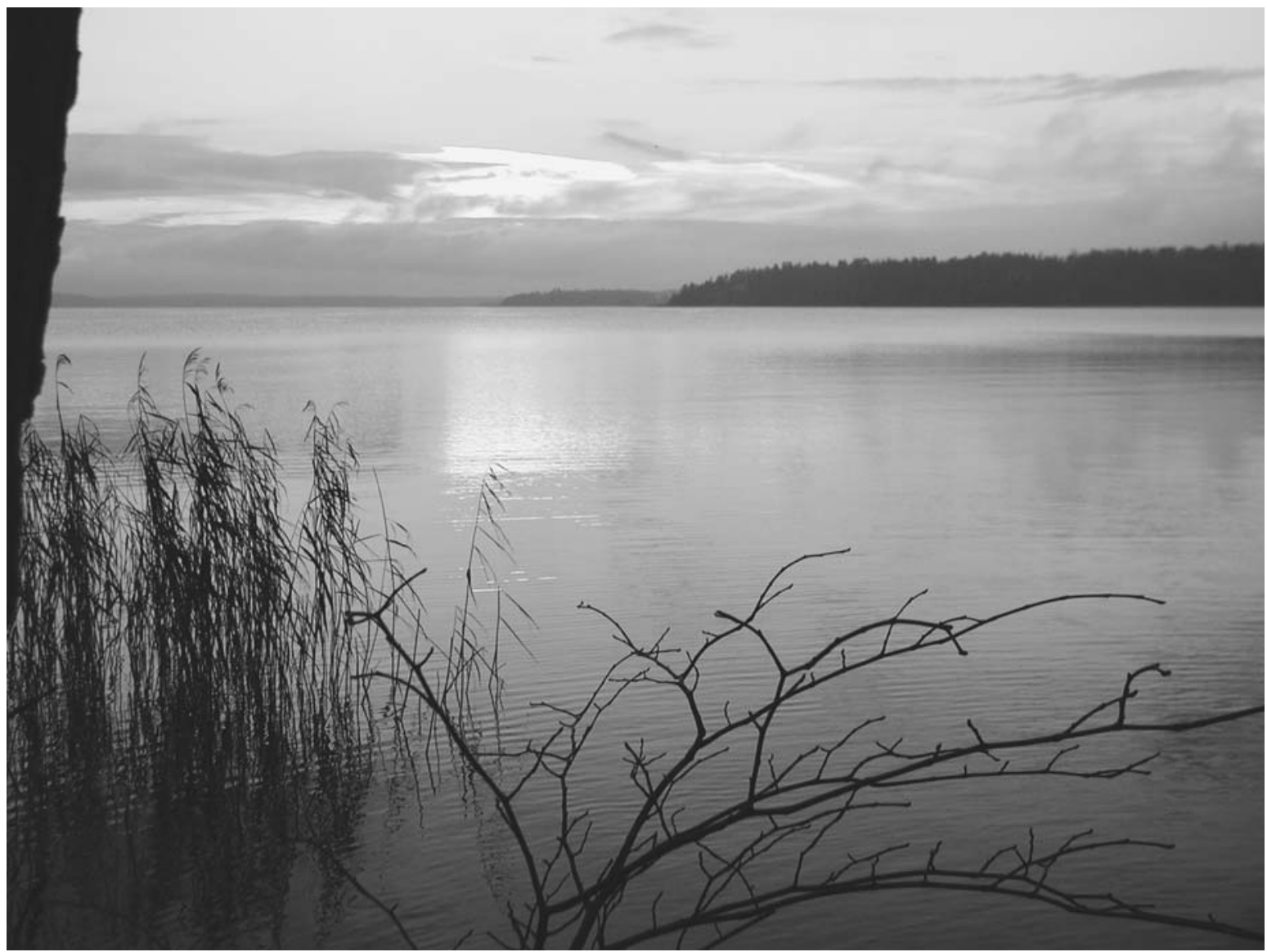

Plate 1. Sunset at Lake Mälaren, Sweden. Photo credit: Gert Nilsson.

used, were analyzed by denaturing gradient gel electrophoresis (DGGE). The fungal DNA was extracted with a DNA purification kit (UltraClea Soil DNA Isolation Kit, Mo Bio Labs, Solana Beach, California, USA). Polymerase chain reaction (PCR) amplification of $18 \mathrm{~S}$ rDNA was performed using the primers GCFung and NS1 (May et al. 2001). The PCR was performed with 2min denaturation at $95^{\circ} \mathrm{C}$ followed by 30 cycles of $30 \mathrm{~s}$ at $94^{\circ} \mathrm{C}, 30 \mathrm{~s}$ at $55^{\circ} \mathrm{C}, 60 \mathrm{~s}$ at $72^{\circ} \mathrm{C}$, and a final extension time of $5 \mathrm{~min}$ at $72^{\circ} \mathrm{C}$. The PCR product was then separated on a $6 \%$ polyacrylamide gel (denaturating gradient 25-45\%) that was run for $17 \mathrm{~h}$ at $75 \mathrm{~V}$ and $60^{\circ} \mathrm{C}$. Bands formed in the gels were visualized by staining with SYBRGold (Molecular Probes/Invitrogen Labeling \& Detection, Eugene, Oregon, USA) and documented under ultraviolet illumination (Spectroline UV Transilluminator, Spectronics, Westbury, New York, USA). The bands obtained showed that three or four of the five inoculated fungal species grew well in all treatments.

After 2, 7, 15, 29, and 61 days the activities of seven enzymes ( $\beta$-glucosidase, $\beta$-xylosidase, cellobiohydrolase, phenol oxidase, leucine-aminopeptidase, $\beta$-N-acetylglucosaminidase, and phosphatase) were analyzed through destructive sampling of four replicates (tubes) for each enzyme from each treatment. Further replicate samples (tubes) were taken for analysis of fungal biomass, which were stored frozen (four replicates), and for bacterial density (four replicates), preserved with $2 \%$ formalin at $4^{\circ} \mathrm{C}$. Six additional sterile replicates of each treatment were used as controls in the enzyme measurements, along with seven blanks (vials with artificial lake water only).

\section{Enzymatic activities}

The enzymes $\beta$-glucosidase (EC 3.2.1.21), $\beta$-xylosidase (EC 3.2.1.37), cellobiohydrolase (EC 3.2.1.91), $\beta-\mathrm{N}$ acetylglucosaminidase (EC 3.2.1.30), and phosphatase (EC 3.1.3.1-2) were analyzed by using fluorescent (MUF, methylumbelliferone)-linked artificial substrates (MUF- $\beta$-D-glucopyranoside [Fluka, Buchs, Switzerland], MUF- $\beta$-D-xylopyranoside [ACROS, Organics, Geel, Belgium], MUF-cellobioside [Sigma-Aldrich Sweden AB, Stockholm, Sweden], MUF-N-acetyl- $\beta$-Dglucosaminide [ACROS], and MUF-phosphate [Fluka]. Leucine-aminopeptidase (EC 3.4.11.1) was analyzed by the fluorescent-linked artificial substrate L-leucine-4methyl-7-coumarinylamide hydrochloride (Leu-AMC [7-amino-4-methylcoumarin], from Fluka). Phenol oxidase activity (EC 1.10.3.2 and 1.14.18.1) was measured 
by using L-3,4-dihydroxyphenylalanine (L-DOPA, from ACROS).

In a preliminary experiment, leaves were incubated for $7 \mathrm{~d}$, whereupon saturation curves for each of the seven enzymes were produced for the treatments $\mathrm{B}, \mathrm{F}$, and $\mathrm{L}$. Based on this preliminary experiment, we later used 0.3 $\mathrm{mmol} / \mathrm{L}$ substrate for the $\beta$-glucosidase, $\beta$-xylosidase, phoshatase, leucine-aminopeptidase, and $\beta$-glucosaminidase, $0.8 \mathrm{mmol} / \mathrm{L}$ substrate for the cellobiohydrolase, and $5 \mathrm{mmol} / \mathrm{L}$ for the phenol oxidase activity. Controls were incubated to correct the fluorescence for fluorescent organic matter in the water, which accounted for about $2-5 \%$ of the fluorescence of the samples. Additional blanks with artificial lake water plus artificial substrate were incubated to correct for the non-biotic degradation of the artificial substrate. Fluorescence of these blanks was between $0.2 \%$ and $2 \%$ of the fluorescence of the samples (depending on the enzyme). For the photometric phenol oxidase assay, the absorbance of the controls reached values corresponding to $50 \%$ of the sample absorbance.

After substrate addition, samples were placed on a shaker at $20^{\circ} \mathrm{C}$ in darkness for $1 \mathrm{~h}$. Thereafter, glycine buffer $(0.05 \mathrm{mmol} / \mathrm{L}$, pH $10.4,1: 2$ buffer:sample, volume: volume, $6 \mathrm{~mL}$ ) was added to each sample and to three replicates of each treatment as a substrate control. Standards of MUF and AMC $(0-50 \mu \mathrm{mol} / \mathrm{L})$ were prepared with artificial lake water and added to glycine buffer (1:2 buffer:standard, volume:volume). Fluorescence was measured at $455 \mathrm{~nm}$ upon excitation at $365 \mathrm{~nm}$ with a FluoroMax-2 fluorometer (Jobin YvonSpex, Instruments S.A., Edison, New Jersey, USA).

Phenol oxidase activity was measured following the method outlined by Sinsabaugh et al. (1994). Incubations (2h) were performed at $5 \mathrm{mmol} / \mathrm{L}$ L-DOPA concentration with $\mathrm{pH} 5$ acetate buffer. Triplicate controls of each treatment (without L-DOPA) and artificial lake water (with and without L-DOPA) were included. Samples were incubated at $20^{\circ} \mathrm{C}$ on agitation in darkness. At the end of incubations, samples were centrifuged at $2000 \mathrm{~g}\left(19614 \mathrm{~m} / \mathrm{s}^{2}\right)$ for $2 \mathrm{~min}$, and the absorbance of the liquid phase was measured at $460 \mathrm{~nm}$ (Perkin Elmer UV/VIS Spectrometer, Lambda 40).

\section{Bacterial and fungal biomass}

Bacterial biomass.-Samples for analysis of bacterial density were homogenized in a kitchen mixer. Sodium pyrophosphate was added to a final concentration of $0.05 \mathrm{mmol} / \mathrm{L}$. After $30 \mathrm{~min}$, samples were sonicated using a probe to detach bacteria from the litter (Microson XL ultrasonic cell disruptor; Heat Systems, Farmingdale, New York, USA), 2 min sonication, then $\sim 5$ min cooling on ice, then 2 min sonication (Velji and Albright 1993). After appropriate dilution with $0.2-\mu \mathrm{m}$ filtered Milli-Q water, samples were stained with DAPI (4',6'-diamidino-2-phenylindole hydrochloride, Sigma) for 20 min (Porter and Feig 1980) and collected on black $0.2-\mu \mathrm{m}$ polycarbonate filters (GE Osmonics Labstore,
Minnetonka, Minnesota, USA). Counting of bacteria was performed using a Nikon epifluorescence microscope (25 fields and about 300-700 cells were counted per sample). Bacterial biomass was estimated by using the average conversion factor $43 \mathrm{fg} \mathrm{C} /$ cell, which was obtained by Mille-Lindblom and Tranvik (2003) for bacterial cells growing on Phragmites litter.

Fungal biomass.-Each frozen sample was homogenized with a mill (Analytical mill A11 basic; IKA Works, Wilmington, North Carolina, USA), lyophilized, and stored frozen until analysis of ergosterol, which was used as a measure of fungal biomass. Extraction and high-performance liquid chromatography (HPLC) analysis of ergosterol were performed as described by MilleLindblom and Tranvik (2003) with some minor modifications of the method. About $45 \mathrm{mg}$ of each sample was used for the analysis. After extraction, the samples were filtered using $0.45 \mu \mathrm{m}$ PTFE (polytetrafluoroethylene) Mini-UniPrep filters (Whatman, VWR International, Stockholm, Sweden), and analyzed with a HPLC system from Gilson (Lewis Center, Ohio, USA) equipped with a cartridge guard system and a Phenomenex column (ShereClone $5 \mu$ ODS (2) $250 \times 4.60 \mathrm{~mm}$; Phenomenex USA, Torrance, California, USA). The peak appeared after about 13.7 minutes at $23^{\circ} \mathrm{C}$. Fungal carbon biomass was estimated based on an ergosterol content of $5.5 \mathrm{mg} / \mathrm{g}$ fungal biomass (Gessner and Chauvet 1993, Charcosset and Chauvet 2001), and a $43 \%$ carbon content of fungi (Baldy et al. 1995, Baldy and Gessner 1997).

\section{Statistical analyses}

Fungal and bacterial biomass and extracellular enzyme activities were analyzed by using a two-way ANOVA to test for the effect of treatment, sampling time, and time $\times$ treatment interaction. All data were logarithmically transformed to stabilize the variance. Probabilities were adjusted by the Dunn-Sidak correction. Post hoc comparisons (Tukey's hsd test) were used to analyze differences between specific treatments. Differences at day 61 between $\mathrm{B}$ and $\mathrm{F}$ treatments and the control for bacterial and fungal biomass were analyzed by a $t$ test. The activity of each enzyme for the entire experimental period (61 d) was calculated by trapezoid integration. All possible combinations of the replicate enzyme activities from each sampling date (in total 1024 combinations) were considered to obtain the mean and $95 \%$ confidence interval of the integrated activity.

\section{RESUlts \\ Bacterial and fungal biomass}

Bacteria reached significantly higher biomass in the nonsterilized leaves (L) and fungi + bacteria $(\mathrm{F}+\mathrm{B})$ treatments than in the bacteria-only (B) treatment, suggesting that bacterial growth was stimulated by the presence of fungi (two-way ANOVA, treatment effect, $P$ $=0.003$; Fig. 1, Table 1). Accordingly, the rate of increase in biomass during the first week was highest in 

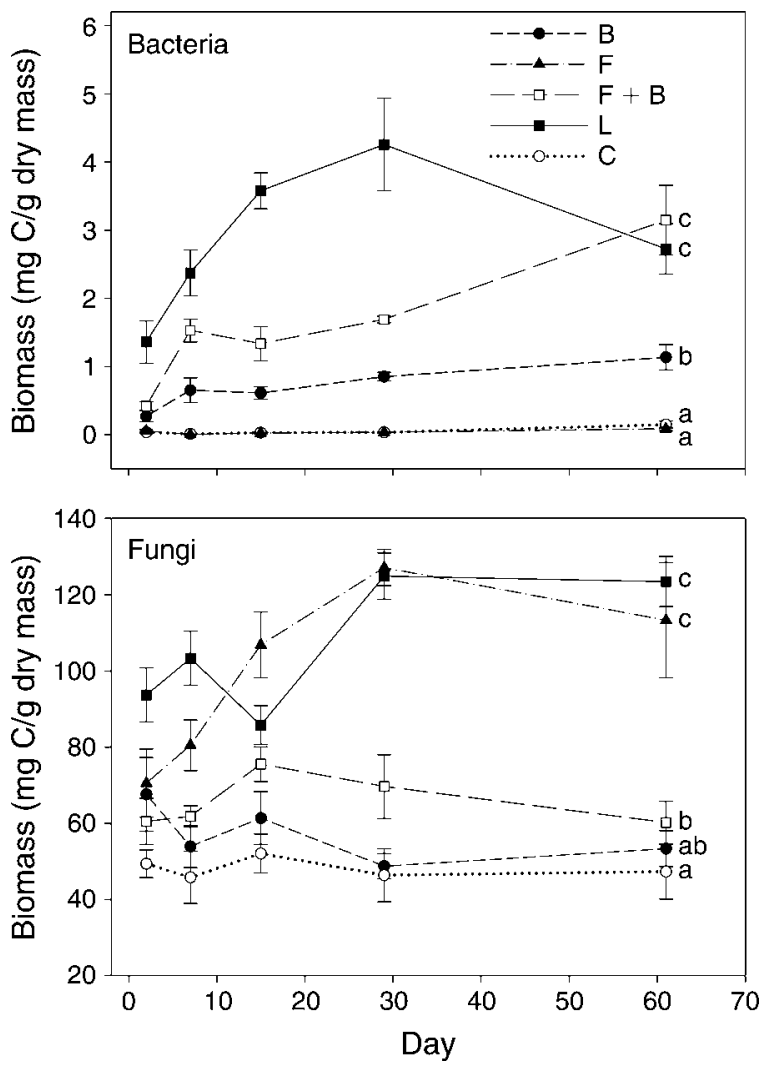

FIG. 1. Development of bacterial and fungal biomass for the different treatments $(\mathrm{B}=$ bacteria only, $\mathrm{F}=$ fungi only, $\mathrm{F}+\mathrm{B}$ $=$ fungi plus bacteria, $\mathrm{L}=$ nonsterilized leaves, $\mathrm{C}=$ control). Data are means $\pm \operatorname{SE}(n=4$ replicate samples). Lowercase letters indicate significantly different groups found by Tukey's hsd test $(P<0.05)$. these treatments (two-way ANOVA, time and treatment $\times$ time effect, $P=0.003$; Fig. 1). No significant differences in bacterial density were observed between the $\mathrm{F}$ and the sterile-control (C) treatments, indicating that the $\mathrm{F}$ treatment had no bacterial contamination (Fig. 1).

Fungal biomass in the $\mathrm{F}$ treatment increased steeply until day 29, reaching the same values as the $\mathrm{L}$ treatment (Fig. 1, Table 1). In contrast, fungal growth in the $\mathrm{F}+\mathrm{B}$ treatment was slow. Two-way ANOVA revealed significant differences in fungal biomass between treatments $(P=0.003)$ but no significant effect of time (time and treatment $\times$ time effects, $P=0.93, P=0.08$, respectively). The control and B treatments grouped together with low fungal biomass (Fig. 1), and the occurrence of ergosterol in these treatments probably remained within dead fungi (Mille-Lindblom et al. 2004).

\section{Enzymatic activities}

The expression of all measured enzyme activities differed significantly among the treatments (two-way ANOVA, $P=0.003$ ), and with the exception of phenol oxidase they also differed significantly over time $(P=$ 0.003 , but $P=0.631$ and $P=0.054$ for phenol oxidase time, and treatment $\times$ time interaction, respectively; Fig. $2)$. The enzymatic activities related to cellulose and hemicellulose decomposition ( $\beta$-glucosidase, $\beta$-xylosidase and cellobiohydrolase) increased steeply in the $\mathrm{F}$ treatment, while the activity in the $\mathrm{F}+\mathrm{B}$ treatment increased more slowly (Fig. 2). In the B treatment $\beta$ glucosidase and $\beta$-xylosidase activities were much lower, and the cellobiohydrolase activity was not significantly different from the activity in the control (Fig. 2).

Lignin decomposition (phenol oxidase activity) was highest in the $\mathrm{L}$ and $\mathrm{F}$ treatments followed by the $\mathrm{F}+\mathrm{B}$

TABLE 1. Bacterial and fungal biomass, specific enzyme activities (expressed per gram of microbial C) and the phosphatase : leucine-aminopeptidase ratio after 61 days of the incubation of Phragmites leaves.

\begin{tabular}{|c|c|c|c|c|}
\hline & \multicolumn{4}{|c|}{ Treatment $\dagger$} \\
\hline & Bacterial, B & Fungal, F & $\mathrm{F}+\mathrm{B}$ & Leaves, L \\
\hline \multicolumn{5}{|c|}{ Microbial biomass (mg C/g dry mass) } \\
\hline $\begin{array}{l}\text { Bacterial biomass } \\
\text { Fungal biomass }\end{array}$ & $\begin{array}{c}0.99^{\mathrm{a}}(0.37) \\
0 f\end{array}$ & $66.0^{\mathrm{b}} \stackrel{0 \ddagger}{(30.35)}$ & $\begin{array}{cl}3.00^{\mathrm{b}} & (1.02) \\
12.9^{\mathrm{a}} & (11.18)\end{array}$ & $\begin{array}{ll}2.58^{\mathrm{b}} & (0.74) \\
76.2^{\mathrm{b}} & (13.15)\end{array}$ \\
\hline \multicolumn{5}{|c|}{ Specific enzyme activities $\left(\mathrm{mmol} \cdot \mathrm{g} \mathrm{C}^{-1} \cdot \mathrm{h}^{-1}\right)$} \\
\hline $\begin{array}{l}\beta \text {-Glucosidase } \\
\beta \text {-Xylosidase } \\
\text { Cellobiohydrolase } \\
\text { Glucosaminidase } \\
\text { Phenol oxidase } \\
\text { Phosphatase } \\
\text { Leucine-aminopeptidase }\end{array}$ & $\begin{array}{l}0.91^{\mathrm{bc}}(0.51) \\
0.49^{\mathrm{b}}(0.27) \\
0 \dagger^{0} \\
0.81^{\mathrm{ab}}(0.63) \\
1.50^{\mathrm{b}}(0.24) \\
2.30^{\mathrm{b}}(0.53)\end{array}$ & $\begin{array}{l}0.51^{\mathrm{ab}}(0.05) \\
0.25^{\mathrm{ab}}(0.05) \\
0.26^{\mathrm{a}}(0.06) \\
0.48^{\mathrm{a}}(0.03) \\
0.083^{\mathrm{a}}(0.072) \\
0.31^{\mathrm{a}}(0.10) \\
0.003^{\mathrm{a}}(0.001)\end{array}$ & $\begin{array}{ll}1.19^{\mathrm{c}} & (0.25) \\
0.37^{\mathrm{ab}} & (0.06) \\
0.46^{\mathrm{a}} & (0.30) \\
1.26^{\mathrm{b}} & (0.31) \\
0.071^{\mathrm{a}} & (0.082) \\
1.45^{\mathrm{b}} & (0.27) \\
0.24^{\mathrm{a}} & (0.17)\end{array}$ & $\begin{array}{ll}0.33^{\mathrm{a}} & (0.02) \\
0.21^{\mathrm{a}} & (0.03) \\
0.26^{\mathrm{a}} & (0.05) \\
0.27^{\mathrm{a}} & (0.01) \\
0.032^{\mathrm{a}} & (0.024) \\
0.35^{\mathrm{a}} & (0.06) \\
0.023^{\mathrm{a}} & (0.005)\end{array}$ \\
\hline Phosphatase : Peptidase & 0.65 & 98.81 & 6.16 & 14.83 \\
\hline
\end{tabular}

Notes: Biomass and activities are corrected for the values in the control (C) treatment. Values are means with SD in parentheses; $n$ $=4$ replicate samples. Specific activities are obtained by dividing the corrected activity at day 61 by the microbial biomass (sum of mean values for bacteria and fungi). Treatments with different lowercase letters are statistically different (ANOVA with Tukey's hsd test, $P<0.05$ ).

$\uparrow$ Treatments: $\mathrm{B}=$ bacteria only, $\mathrm{F}=$ fungi only, $\mathrm{F}+\mathrm{B}=$ fungi plus bacteria, $\mathrm{L}=$ nonsterilized Phragmites australis leaves.

$\$$ These biomasses and activities were not significantly different between the bacterial and control treatments at day $61(t$ test, $P$ $>0.05$ ). 

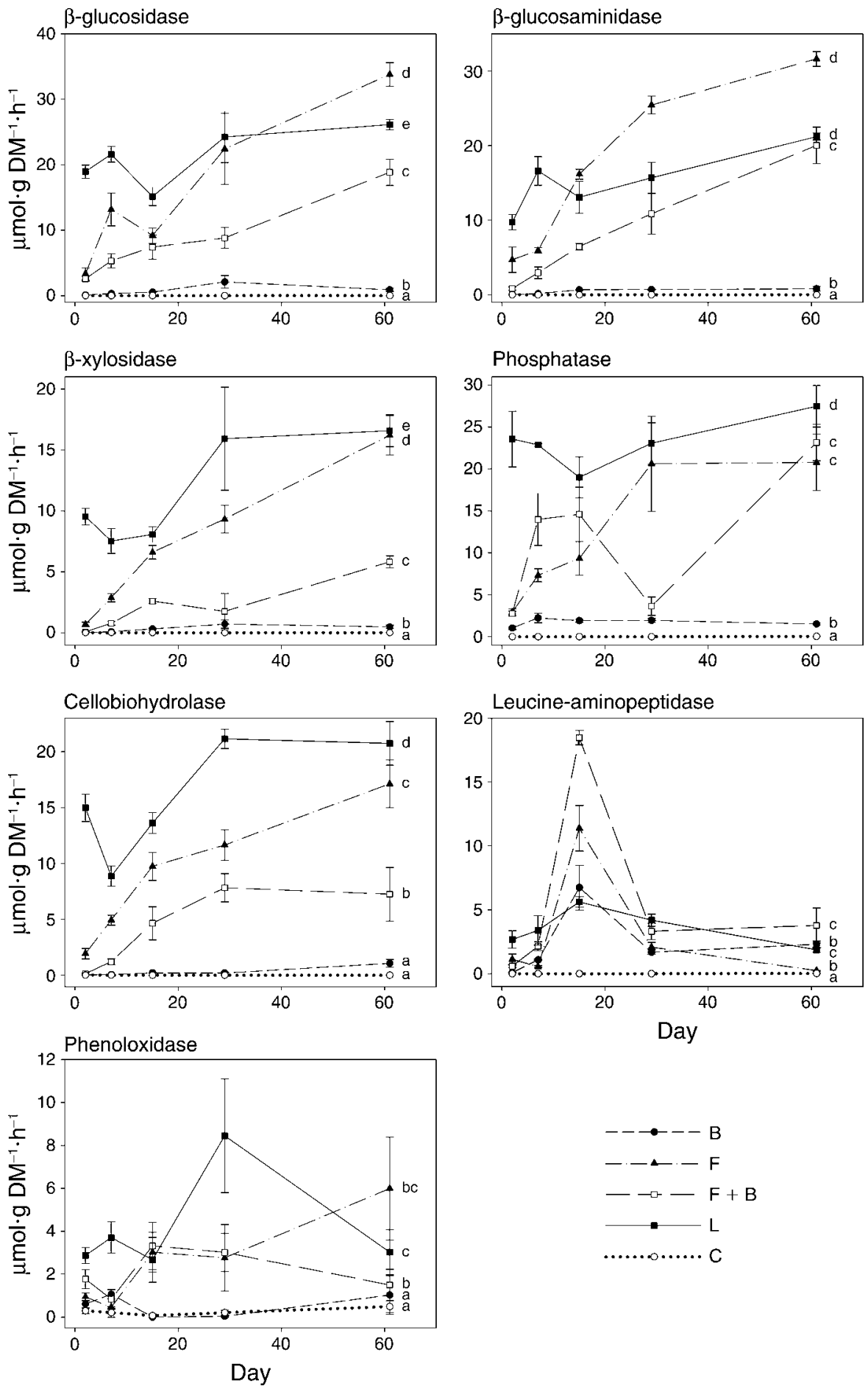

Day

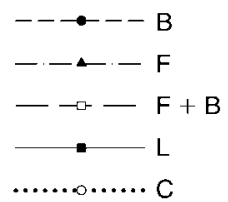

Fig. 2. Development of extracellular enzyme activities for the different treatments $(B=$ bacteria only, $F=$ fungi only, $F+B=$ fungi plus bacteria, $\mathrm{L}=$ nonsterilized leaves, $\mathrm{C}=\mathrm{control})$. Data are means $\pm \operatorname{SE}(n=4$ replicate samples). Lowercase letters indicate significantly different groups found by Tukey's hsd test $(P<0.05)$.

treatment (Fig. 2). Phenol oxidase activity in the B treatment was not significantly different from the $\mathrm{C}$ treatment. (Fig. 2). Chitin decomposition ( $\beta$-glucosaminidase activity) was high and increased throughout the experimental period in all treatments with fungi (Fig. 2). The activity of $\beta$-glucosaminidase in the B treatment was much lower (Fig. 2), but clearly distinguishable from the level in $\mathrm{C}$. 

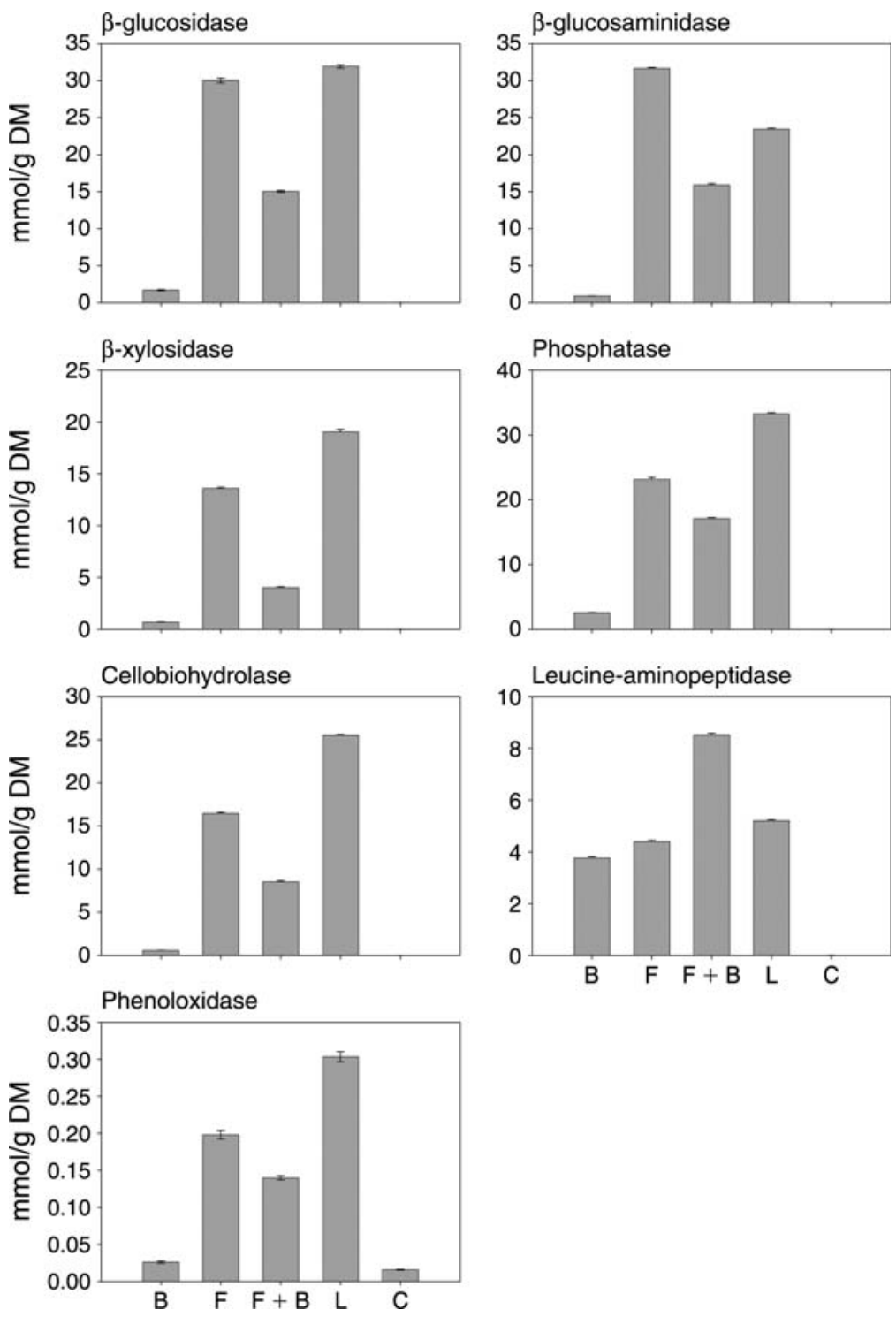

FIG. 3. Integrated enzyme activities for the different treatments for the whole experimental period (61 days) (B=bacteria only, $\mathrm{F}=$ fungi only, $\mathrm{F}+\mathrm{B}=$ fungi plus bacteria, $\mathrm{L}=$ nonsterilized leaves, $\mathrm{C}=$ control). Values are means $\pm 95 \%$ confidence intervals.

In contrast to the other enzymatic activities, no significant difference between the treatments $\mathrm{F}+\mathrm{B}$ and $\mathrm{F}$ were found for the phosphatase activity. A different pattern was observed also for the leucine-aminopeptidase activity, where the treatments $\mathrm{F}$ and $\mathrm{B}$ are grouped and with lower values than the treatments $\mathrm{F}+\mathrm{B}$ and $\mathrm{L}$ (Fig. 2). Hence, the activity of this enzyme appeared to be stimulated by the co-existence of fungi and bacteria. Leucine-aminopeptidase showed a drastic peak at day 15 for the treatments $\mathrm{F}+\mathrm{B}, \mathrm{F}$, and $\mathrm{B}$.

We calculated the microbial biomass-specific enzyme activities as an indicator of efficiency for decomposition of organic compounds (Table 1). Bacterial specific enzyme activities were high for $\beta$-glucosidase, $\beta$-xylosidase, $\beta$-glucosaminidase, and phosphatase, and very high for leucine-aminopeptidase. These bacterial enzyme activities might contribute to the also high biomassspecific enzyme activities measured for the $\mathrm{F}+\mathrm{B}$ treatment (Table 1). In contrast, fungi exhibited higher specific enzyme activities for phenol oxidase and cellobiohydrolase (Table 1). The phosphatase: peptidase ratio was highest in the $\mathrm{F}$ treatment and lowest in the $\mathrm{B}$ treatment (Table 1). The $\mathrm{F}+\mathrm{B}$ and $\mathrm{L}$ treatments showed similar phosphatase: peptidase ratios.

Enzyme activities integrated throughout the time course of the experiment (Fig. 3) were high in fungionly treatment (except for decomposition of peptides), and lowest in the bacteria-only treatment. Although bacteria contributed less than fungi to the total activities, enzyme activities were to some extent con- 
trolled by bacteria, as suggested by the depression in the $\mathrm{F}+\mathrm{B}$ treatment as compared to the F treatment (Fig. 3). The effect of bacteria on the fungal enzyme activity appeared to be due to the suppression of fungal biomass development (Fig. 1) rather than a specific bacterial effect on enzyme activity, as shown by the high specific activities recorded in the $\mathrm{F}+\mathrm{B}$ treatment (Table 1). As expected, the natural leaves, that were already colonized from the beginning of the experiment, accumulated the highest enzyme activity during the experiment, with the exception of the $\beta$-glucosaminidase which was highest in the $\mathrm{F}$ treatment, and leucine-aminopeptidase, which was highest in the $\mathrm{F}+\mathrm{B}$ treatment. Leucine-aminopeptidase was the only enzyme where bacteria accounted for a large fraction of the total activity, as demonstrated by the high biomass-specific peptidase activity in the bacteria-only treatment. This coincided with leucineaminopeptidase being the only enzyme where co-existing bacteria and fungi expressed higher enzyme activity than the fungi alone.

\section{DisCUSSION}

Fungi and bacteria in decomposer communities on plant litter play broadly similar roles as degraders of organic matter, but are phylogenetically distant and represent fundamentally different life forms (single cells vs. filaments) and a range of other specific traits (Fenchel et al. 2000). As a consequence, fungal structure and physiology permits the decomposition of vascular plant material that bacteria cannot gain access to (Suberkropp and Klug 1976, Gessner and Chauvet 1994). Only actinomycetes can grow efficiently on recalcitrant polymers such as lignocellulose, although they are less invasive than fungi (Adhi et al. 1989). Previous evidence from microcosm experiments suggests apparent antagonistic interactions between fungi and bacteria in the decomposition of organic matter (Wohl and McArthur 2001, de Boer et al. 2003). This antagonism may influence major ecosystem functions, such as biomass production and mineralization (MilleLindblom and Tranvik 2003). Here, we demonstrate that, in addition to quantitative general effects such as total mineralization and biomass production, the broad interaction between these two domains has qualitative consequences, as shown by different patterns of extracellular enzyme expression. Furthermore, our study highlights that complex interactions between fungi and bacteria occur in aquatic habitats, where this issue has been much less studied than in terrestrial environments.

The enzyme activities and biomass values obtained for the different treatments with autoclaved Phragmites leaves were in the same range as the results in the $\mathrm{L}$ (nonsterilized leaves) treatment. The phosphatase:leucine-aminopeptidase ratio was similar in the $\mathrm{L}$ and $\mathrm{F}+\mathrm{B}$ (fungal plus bacterial inocula) treatment, indicating a similar nutrient status of both treatments. The inclusion of several fungal species might be a relevant factor to mimic the natural conditions. On the other hand, biomass-specific enzyme activities in the $\mathrm{L}$ treatment (natural leaves) were lower than in the $\mathrm{F}+\mathrm{B}$ treatment, which might be a result of an older community in the former, with a higher portion of dead organisms that were still recorded during bacterial counts (Zweifel and Hagström 1995) and ergosterol measurements (MilleLindblom et al. 2004). The similarity between the $\mathrm{L}$ treatment and the $\mathrm{F}+\mathrm{B}$ treatment suggests that the results from experiments on autoclaved leaves are valid. Autoclaving enables the inoculation with defined populations or communities, including the comparison of communities where bacteria or fungi are excluded. Our results suggest that autoclaving, and thus the ability to test hypotheses regarding interactions of specific microbial guilds, does not severely affect the decomposition process.

Incubation of only fungi resulted in a fast increase of their biomass (Fig. 1). Intensive growth of fungi is also underlined by the highest accumulated $\beta$-glucosaminidase activity in the only-fungal $(F)$ treatment throughout the experiment (Fig. 3), since this enzyme is involved in the construction of new fungal cell wall and especially enhanced during fungal growth (Chamier 1985, Rast et al. 2003). The fungi-only community clearly showed a high capacity for the decomposition of plant polymers, such as lignin, cellulose, and hemicellulose (Fig. 2, Table 1). However, specific enzyme activities related to the use of simple molecules of $\mathrm{C}, \mathrm{N}$, and $\mathrm{P}(\beta$-glucosidase and $\beta$ xylosidase, $\beta$-glucosaminidase, peptidase, phosphatase, Table 1) were lower in the fungi-only treatment.

In contrast, bacteria growing alone (B) colonized the litter slowly (Fig. 1) although their higher biomassspecific enzyme activities suggest that they are more efficient in the utilization of most substrates (Table 1). The low bacterial-biomass accrual may be due to enzymatic limitations, including the apparently very low ability to employ phenol oxidase and cellobiohydrolase in the bacterial acquisition of carbon from very common plant polymers. Hence, it is possible that bacteria had no (or very low) capacity for the degradation of lignin and polymeric cellulose. However, biomass-specific enzyme activities related to the acquisition of the nutrients phosphorus and nitrogen (phosphatase and peptidase) were much higher for bacteria than for fungi (Table 1). The higher bacterial production of enzymes associated with nutrient assimilation is probably due to the stoichiometric differences between bacteria and fungi. Bacterial cells have high levels of $\mathrm{P}$ and N (Vrede et al. 2002, Makino et al. 2003) while these compounds in general appear in lower concentrations in fungal tissue (Cromack and Caldwell 1992).

When bacteria and fungi grew together their respective biomass accumulation and the expression of enzyme capabilities were affected. Bacteria grew better together with fungi than alone. It is probable that bacteria utilized intermediate decomposition products released by fungi (Fischer et al. 2006). The growth of bacteria (together with fungi) on the refractory 
Phragmites leaves (Farmer and Morrison 1964) further suggests that bacteria benefit from fungal enzyme activity. Lignin and cellulose generally constitute a major share of the reduced carbon in plants. The mobilization of this energy by fungi and transformation into intermediate organic substrates that the bacteria are able to compete for may explain the stimulation of bacteria caused by fungal presence. The low hydrolytic activities measured in several bacterial communities have been suggested to be caused by preferential feeding by bacteria on simple organic molecules released by fungi (Sala and Güde 2004). The synergistic relationship between fungi and bacteria could also be due to the close spatial relationship between the two groups, with bacteria as epiphytes on fungi (Bengtsson 1992). Gulis and Suberkropp (2003b) observed growth of bacteria associated with living and senescent fungal hyphae as well as a higher bacterial production when fungi and bacteria grow together in a microcosm, and fungal hyphae provide additional surface area available for bacterial colonization (Suberkropp and Klug 1976).

The stimulation of bacteria by fungi was accompanied by a negative effect of bacteria on fungal growth, as previously demonstrated (Mille-Lindblom and Tranvik 2003). Delay of fungal sporulation and conidia production in the presence of bacteria was observed by Gulis and Suberkropp (2003b). Wohl and McArthur (2001) found both increase but on some occasions also decrease of $\beta$-glucosidase and enzymes related to chitin degradation when inoculating fungi and actinomycetes together. Møller et al. (1999) observed a depression of $\beta-\mathrm{N}$-acetylglucosaminidase and endo- and exocellulase when bacteria and fungi were inoculated together during decomposition of beech leaves. Such antagonistic effects could be due to the bacterial release of lytic agents and/ or antibiotics but also to competition for the available organic compounds (Mille-Lindblom et al. 2006). Leucine-aminopeptidase activity increases during decay processes (Halemejko and Chróst 1986, Middelboe et al. 1995). Consequently, the high leucine-aminopeptidase activity especially in the $\mathrm{F}+\mathrm{B}$ treatment might indicate the occurrence of cell lysis of fungi caused by the presence of bacteria. Bacterial lysis of fungal cell walls is suggested by the high biomass-specific $\beta$-glucosaminidase activity in the $\mathrm{F}+\mathrm{B}$ treatment (Table 1; Wohl and McArthur 2001).

Apparently, the bacteria exploited only a minor part of the available resources, regardless of whether fungi were present or not, and despite the fact that bacteria exerted a strong regulation on the much more abundant fungi. On the other hand, bacteria might express a high affinity for the available organic substrates, especially polysaccharides, as shown by the higher efficiency in using such simple polysaccharidic molecules ( $\beta$-glucosidase, $\beta$-xylosidase; Table 1). The efficiency in the use of simpler organic compounds might give a competitive advantage to bacteria over fungi. Antagonism related to competition for leaf carbon in a microcosm system was suggested by Møller et al. (1999).

The higher biomass-specific activities of most enzymes involved in the use of simple $\mathrm{C}, \mathrm{N}$, and $\mathrm{P}$ compounds for bacteria (in particular phosphatase and peptidase; Table 1) suggest that bacterial contribution to the $F+B$ treatment was considerable. Furthermore, the higher biomass-specific enzyme activity in the $\mathrm{F}+\mathrm{B}$ treatment can also be due to increasing fungal enzyme activity as a response to the negative effect of bacteria on fungi, which retards fungal biomass accrual but might accelerate fungal turnover rate. As has been observed in the relationship between two hyphomycete species, competition can have a positive effect on function, i.e. decomposition rates (Treton et al. 2004).

The outcome of this cultured-based experiment cannot be linked without caution to natural aquatic ecosystems. Nevertheless, our experiment suggests that interactions between bacteria and fungi may have a substantial impact on their activities, which should be considered in future studies of the dynamics of microbial degradation. Our results indicate both antagonistic and synergistic interactions between fungi and bacteria. These interactions may influence the decomposition process by altering the growth and hence also the enzyme production of the microorganisms, and thereby also the rate and quality of released dissolved organic matter and intermediate decomposition products. Synthesis of extracellular enzymes by fungi enables generation of carbon substrates allowing continued growth and synthesis of enzymes. This results in a feedback loop where a substantial biomass is built up. As demonstrated by Schimel and Weintraub (2003), a limited diversion of the $\mathrm{C}$ substrates generated by the extracellular enzymes may cause a drastic decline in biomass production. Possibly, bacterial use of $\mathrm{C}$ substrates generated by fungal enzymes represents such a diversion, which may explain how a small bacterial biomass could severely limit the development of significantly larger fungal biomass. Competition from bacteria, acting as "cheaters" by using the simple compounds released by fungal enzyme activity (Velicer 2003), would limit the enzymatic decomposition of complex compounds in natural environments (Allison 2005) by limiting the growth of cellulolytic and ligninolytic enzyme producers (fungi).

Our results support previous findings of bacterial suppression of fungi (Mille-Lindblom and Tranvik 2003), but also demonstrate dependence of bacteria on the enzymatic activity exerted by fungi. Accordingly, the degradation of litter is not simply the sum of the activities of the various degraders, but rather involves complex interactions among different populations. These interactions include suppression of growth as well as facilitation due to release of substrates, and fungi and bacteria exhibit distinctly different decomposer strategies. 


\section{ACKNOWLEDGMENTS}

We thank two anonymous reviewers for their comments and valuable suggestions. Kristiina Nygren and Markus Forslund are acknowledged for valuable assistance with laboratory analyses. Hampus Markensten provided helpful advice on data analysis. The study was supported by a grant to L. J. Tranvik from the Swedish Research Council. A. M. Romaní received a grant to participate in this project (Beques BE de la Generalitat de Catalunya).

\section{Literature Cited}

Abdel-Raheem, A., and C. A. Shearer. 2002. Extracellular enzyme production by freshwater ascomycetes. Fungal Diversity 11:1-19.

Adhi, T. P., R. A. Korus, and D. L. Crawford. 1989. Production of major extracellular enzymes during lignocellulose degradation by two streptomycetes in agitated submerged culture. Applied and Environmental Microbiology 55:1165-1168.

Allison, S. D. 2005. Cheaters, diffusion and nutrients constrain decomposition by microbial enzymes in spatially structured environments. Ecology Letters 8:626-635.

Anesio, A. M., P. C. Abreu, and B. A. Biddanda. 2003. The role of free and attached microorganisms in the decomposition of estuarine macrophyte detritus. Estuarine, Coastal, and Shelf Science 56:197-201.

Baldy, V., and M. O. Gessner. 1997. Towards a budget of leaf litter decomposition in a first-order woodland stream. Comptes Rendus de l'Académie des Sciences-Serie IIISciences de la Vie 320:747-758.

Baldy, V., M. O. Gessner, and E. Chauvet. 1995. Bacteria, fungi, and the breakdown of leaf litter in a large river. Oikos 74:93-102.

Bengtsson, G. 1992. Interactions between fungi, bacteria, and beech leaves in a stream mesocosm. Oecologia 89:542-549.

Benner, R., S. Y. Newell, A. E. Maccubbin, and R. E. Hodson. 1984. Relative contributions of bacteria and fungi to rates of degradation of lignocellulosic detritus in salt-marsh sediments. Applied and Environmental Microbiology 48:36-40.

Bucher, V. V. C., K. D. Hyde, S. B. Pointing, and C. A. Reddy. 2004. Production of wood decay enzymes, mass loss and lignin solubilization in wood by marine ascomycetes and their anamorphs. Fungal Diversity 15:1-14.

Chamier, A. C. 1985. Cell-wall-degrading enzymes of aquatic hyphomycetes: a review. Botanical Journal of the Linnean Society 91:67-81.

Charcosset, J. Y., and E. Chauvet. 2001. Effect of culture conditions on ergosterol as indicator of biomass in the aquatic hyphomycetes. Applied and Environmental Microbiology 67:2051-2055.

Chróst, R. J. 1991. Environmental control of the synthesis and activity of aquatic microbial ectoenzymes. Pages 29-59 in J. Chróst, editor. Microbial enzymes in aquatic environments. Springer-Verlag, New York, New York, USA.

Cromack, J. K., and B. A. Caldwell. 1992. The role of fungi in litter decomposition and nutrient cycling. Pages 653-668 in G. C. Carroll and D. T. Wicklow, editors. The fungal community: its organisation and role in the ecosystem. Marcel Dekker, New York, New York, USA.

Deacon, J. W. 1997. Modern mycology. Blackwell Science, Oxford, UK.

de Boer, W., P. Verheggen, P. J. A. Klein Gunnewiek, G. A. Kowalchuk, and J. A. van Veen. 2003. Microbial community composition affects soil fungistasis. Applied and Environmenta Microbiology 69:835-844.

Drews, J. 2000. Drug discovery: a historical perspective. Science 287:1960-1964.

Farmer, V. C., and R. I. Morrison. 1964. Lignin in sphagnum and phragmites and in peats derived from these plants. Geochimica et Cosmochimica Acta 28:1537-1546.
Fenchel, T., G. M. King, and T. H. Blackburn. 2000. Bacterial biogeochemistry: the ecophysiology of mineral cycling. Academic Press, London, UK.

Findlay, S. E. G., S. Dye, and K. A. Kuehn. 2002. Microbial growth and nitrogen retention in litter of Phragmites australis compared to Typha angustifolia. Wetlands 22:616-625.

Fischer, H., C. Mille-Lindblom, E. Zwirnmann, and L. J. Tranvik. 2006. Contribution of fungi and bacteria to the formation of dissolved organic carbon from decaying common reed (Phragmites australis). Archiv für Hydrobiologie 166:79-97.

Fisher, P. J., R. A. Davey, and J. Webster. 1983. Degradation of lignin by aquatic and aero-aquatic hyphomycetes. Transactions of the British Mycological Society 80:166-168.

Gaur, S., P. K. Singhal, and S. K. Hasija. 1992. Microbes associated with decaying litter of aquatic macrophytes in some tropical lakes. Proceedings of the National academy of sciences, India/Section B 62:75-82.

Gessner, M. O., and E. Chauvet. 1993. Ergosterol-to-biomass conversion factors for aquatic hyphomycetes. Applied and Environmental Microbiology 59:502-507.

Gessner, M. O., and E. Chauvet. 1994. Importance of stream microfungi in controlling breakdown rates of leaf litter. Ecology 75:1807-1817.

Gulis, V., and K. Suberkropp. 2003a. Effect of inorganic nutrients on relative contributions of fungi and bacteria to carbon flow from submerged decomposing leaf litter. Microbial Ecology 45:11-19.

Gulis, V., and K. Suberkropp. 2003b. Interactions between stream fungi and bacteria associated with decomposing leaf litter at different levels of nutrient availability. Aquatic Microbial Ecology 30:149-157.

Halemejko, G. Z., and R. J. Chróst. 1986. Enzymatic hydrolysis of proteinaceous particulate and dissolved material in an eutrophic lake. Archiv für Hydrobiologie 107:1-21.

Kirk, T. K., and R. L. Farrell. 1987. Enzymatic combustion: the microbial degradation of lignin. Annual Review of Microbiology 41:465-505.

Kominkova, D., K. A. Kuehn, N. Busing, D. Steiner, and M. O. Gessner. 2000. Microbial biomass, growth, and respiration associated with submerged litter of Phragmites australis decomposing in a littoral reed stand of a large lake. Aquatic Microbial Ecology 22:271-282.

Kuehn, K. A., M. O. Gessner, R. G. Wetzel, and K. Suberkropp. 1999. Decomposition and $\mathrm{CO}_{2}$ evolution from standing litter of the emergent macrophyte Erianteus giganteus. Microbial Ecology 38:50-57.

Kuehn, K. A., M. J. Lemke, K. Suberkropp, and R. G. Wetzel. 2000. Microbial biomass and production associated with decaying leaf litter of the emergent macrophyte Juncus effusus. Limnology and Oceanography 45:862-870.

Lloyd, A. B., and J. L. Lockwood. 1966. Lysis of fungal hyphae in soil and its possible relation to autolysis. Phytopathology 56:595-602.

Makino, W., J. B. Cotner, R. W. Sterner, and J. J. Elser. 2003. Are bacteria more like plants or animals? Growth rate and resource dependence of bacterial C:N:P stoichiometry. Functional Ecology 17:121-130.

May, L. A., B. Smiley, and M. G. Schmidt. 2001. Comparative denaturing gradient gel electrophoresis analysis of fungal communities associated with whole plant corn silage. Canadian Journal of Microbiology 47:829-841.

Middelboe, M., M. Sondergaard, Y. Letarte, and N. H. Borch. 1995. Attached and free-living bacteria: production and polymer hydrolysis during a diatom bloom. Microbial Ecology 29:231-248.

Mille-Lindblom, C., H. Fischer, and L. J. Tranvik. 2006. Antagonism between bacteria and fungi: substrate competition and a possible trade-off between fungal growth and tolerance towards bacteria. Oikos 113:233-242. 
Mille-Lindblom, C., and L. J. Tranvik. 2003. Antagonism between bacteria and fungi on decomposing aquatic plant litter. Microbial Ecology 45:173-182.

Mille-Lindblom, C., E. von Wachenfeldt, and L. J. Tranvik. 2004. Ergosterol as a measure of living fungal biomass: persistence in environmental samples after fungal death. Journal of Microbiological Methods 59:253-262.

Møller, J., M. Miller, and A. Kjøller. 1999. Fungal-bacterial interaction on beech leaves: influence on decomposition and dissolved organic carbon quality. Soil Biology and Biochemistry 31:367-374.

Newell, S. Y. 1993. Decomposition of shoots of a saltmarsh grass: methodology and dynamics of microbial assemblages. Advances in Microbial Ecology 13:301-326.

Porter, K. G., and Y. S. Feig. 1980. The use of DAPI for identifying and counting aquatic microflora. Limnology and Oceanography 25:943-948.

Rast, D. M., D. Baumgartner, C. Mayer, and G. O. Hollenstein. 2003. Cell wall-associated enzymes in fungi. Phytochemistry 64:339-366.

Robb, F., B. R. Davies, R. Cross, C. Kenyon, and C. HowardWilliams. 1979. Cellulolytic bacteria as primary colonizers of Potamogeton pectinatus L. (sago pond weed) from a brackish south-temperate coastal lake. Microbial Ecology 5:167-177.

Rüttimann, C., R. Vicuña, M. D. Mozuch, and T. K. Kirk. 1991. Limited bacterial mineralization of fungal degradation intermediates from synthetic lignin. Applied and Environmental Microbiology 57:3652-3655.

Sala, M. M., and H. Güde. 2004. Ectoenzymatic activities and heterotrophic bacteria decomposing detritus. Archiv für Hydrobiologie 160:289-303.

Schimel, J. P., and M. N. Weintraub. 2003. The implications of exoenzyme activity on microbial carbon and nitrogen limitation in soil: a theoretical model. Soil Biology and Biochemistry 35:549-563.

Shearer, C. A. 1992. The role of woody debris. Pages 77-98 in F. Bärlocher, editor. The ecology of aquatic hyphomycetes. Springer-Verlag, Berlin, Germany.

Sinsabaugh, R. L., M. M. Carreiro, and S. Alvarez. 2002. Enzyme and microbial dynamics during litter decomposition. Pages 249-266 in R. Burns and R. P. Dick, editors. Enzymes in the Environment. Marcel Dekker, New York, New York, USA.

Sinsabaugh, R. L., M. P. Osgood, and S. Findlay. 1994. Enzymatic models for estimating decomposition rates of particulate detritus. Journal of the North American Benthological Society 13:160-169.

Slater, J. H., and D. Lovatt. 1984. Biodegradation and the significance of microbial communities. Pages 439-485 in D. T. Gibson, editor. Microbial degradation of organic compounds. Marcel Dekker, New York, New York USA.

Suberkropp, K. 1992. Aquatic hyphomycete communities. Pages 729-747 in D. T. Wicklow and G. C. Carroll, editors. The fungal community: its organization and role in the ecosystem. Marcel Dekker, New York, New York, USA.

Suberkropp, K., and M. J. Klug. 1976. Fungi and bacteria associated with leaves during processing in a woodland stream. Ecology 57:707-719.

Tanaka, Y. 1993. Aerobic cellulolytic bacterial flora associated with decomposing Phragmites leaf litter in a seawater lake. Hydrobiologia 263:145-154.

Treton, C., E. Chauvet, and J. Y. Charcosset. 2004. Competitive interaction between two aquatic hyphomycete species and increase in leaf litter breakdown. Microbial Ecology 48: 439-446.

Velicer, G. J. 2003. Social strife in the microbial world. Trends in Microbiology 11:330-337.

Velji, M. I., and L. J. Albright. 1993. Improved sample preparation for enumeration of aggregated aquatic substrate bacteria. Pages 139-143 in P. F. Kemp, B. F. Sherr, E. B. Sherr, and J. J. Cole, editors. Handbook of methods in aquatic microbial ecology. Lewis Publishers, Boca Raton, Florida, USA.

Vrede, K., M. Heldal, S. Norland, and G. Bratbak. 2002. Elemental composition (C, N, P) and cell volume of exponentially growing and nutrient-limited bacterioplankton. Applied and Environmental Microbiology 68:2965-2971.

Weller, D. M. 1988. Biological control of soilborne plant pathogens in the rizosphere with bacteria. Annual Review of Phytopathology 26:379-407.

Wohl, D. L., and J. V. McArthur. 2001. Aquatic actinomycetefungal interactions and their effects on organic matter decomposition: a microcosm study. Microbial Ecology 42: 446-457.

Zemek, J., L. Marvanová, L. Kuníák, and B. Kadlecikova. 1985. Hydrolytic enzymes in aquatic hyphomycetes. Folia Microbiologica 30:363-372.

Zweifel, U. L., and Å. Hagström. 1995. Total counts of marine bacteria include a large fraction of non-nucleoid-containing bacteria (ghosts). Applied and Environmental Microbiology 61:2180-2185. 